\title{
Use of Telone II and Temik 15G to Improve Yields and Returns of Cotton Grown in Northwest Florida Fields Infested with Reniform Nematodes ${ }^{1}$
}

\author{
D.J. Zimet, J.L. Smith, J.R. Rich, R.A. Kinloch, and T.D. Hewitt ${ }^{2}$
}

\section{Introduction}

Upland cotton (Gossypium hirsutum L.) is a major agronomic crop in the northern tier of counties in Florida, with an estimated harvest of 91,000 acres in the year 2000 (USDA-FASS, 2001). Reniform nematodes (Rotylenchulus reniformis) are found in $16 \%$ of Florida cotton fields, mainly in the soils of the northwest region (Kinloch and Sprenkel, 1994). Management of this pest is accomplished through the use of nematicides, crop rotation, or a combination of the two practices. Rotation with other agronomic crops is not an option for many growers due to the relatively low prices of other agronomic crops in the state. Because nematode resistance is unavailable in commercial varieties of cotton, nematicides are the only viable nematode management option for growers who grow cotton in monoculture. The two nematicides used and recommended in Florida are Temik 15G and Telone II (Kinloch and Rich, 2000). Nematicide recommendations for reniform nematode management in Florida cotton include 4- to 6-inch banded applications of Temik $15 \mathrm{G}$ at 7 pounds per acre or single-chisel row applications of Telone II at 3 gallons per acre. These recommendations are based solely upon improvement in cotton yield in reniform nematode-infested fields because of the lack of data on economic return. This study was conducted to determine the economic return on investment for growers using different application rates of Telone II and Temik 15G. Incremental costs per pound of increased lint yield due to nematicide addition, net return per pound of increased lint yield, and partial net return per acre were calculated for treatments (Boehlje and Eidman, 1984).

\section{Materials and Methods}

A three-year nematicide study (Kinloch and Rich, 2000) involving four separate test sites infested with reniform nematodes was conducted in loamy sand soils of northwest Florida. Three of the test sites were in Gadsden County ( $80 \%$ sand, $8 \%$ silt, and

\footnotetext{
1. This is EDIS document FE 319, a publication of the Department of Food and Resource Economics, Florida Cooperative Extension Service, Institute of Food and Agricultural Sciences, University of Florida, Gainesville, FL. Published November 2004. Please visit the EDIS website at http://edis.ifas.ufl.edu. 2. D.J. Zimet, former Associate Professor, Department of Food and Resource Economics, North Florida Research and Education Center, Quincy, FL; J.L. Smith, Senior Statistician, Department of Food and Resource Economics, North Florida Research and Education Center, Quincy, FL; R.A. Kinloch, Associate Professor, Department of Entomology and Nematology, West Florida Research and Education Center, Jay, FL; J.R. Rich, Professor, Department of Entomology and Nematology, North Florida Research and Education Center, Quincy, FL; and T.D. Hewitt, Professor, Department of Food and Resource Economics, North Florida Research and Education Center, Marianna, FL, Florida Cooperative Extension Service, Institute of Food and Agricultural Sciences, University of Florida, Gainesville, FL.
}

The Institute of Food and Agricultural Sciences (IFAS) is an Equal Employment Opportunity - Affirmative Action Employer authorized to provide research, educational information and other services only to individuals and institutions that function without regard to race, creed, color, religion, age, disability, sex, sexual orientation, marital status, national origin, political opinions or affiliations. For information on obtaining other extension publications, contact your county Cooperative Extension Service office. Florida Cooperative Extension Service / Institute of Food and Agricultural Sciences / University of Florida / Larry R. Arrington, Interim Dean 
$12 \%$ clay) and one test site was in Santa Rosa County ( $82 \%$ sand, $10 \%$ silt, and $8 \%$ clay). These are typical soils for the cotton production areas of Florida. In 1995, tests were conducted in both Gadsden and Santa Rosa Counties and, in 1997 and 1998, tests were conducted only in Gadsden County.

Four rates of Telone II and five rates of Temik $15 \mathrm{G}$ were used in these tests. Each treatment was replicated six times in the 1995 tests and five times in the 1997 and 1998 tests. The trials included replicated non-treated check plots. Nematicide treatments were applied to plots 2 rows wide and 7.6 meters long with 91 centimeter-wide centers. The fumigant Telone II was applied 12 inches deep with a single chisel beneath the row at rates of 1.5, 3, 4.5, and 6 gallons per acre 14 to 17 days prior to planting. Thimet 20G was added to the Telone II tests and the non-treated checks at a rate of 5 pounds per acre to manage thrips. It was assumed there was no additional application cost for Thimet $20 \mathrm{G}$ other than the chemical cost because it was applied at planting time. Granular Temik $15 \mathrm{G}$ was applied in a 6 -inch-wide band and incorporated at planting at rates of 3, 7, 9, and 12 pounds per acre in the 1995 tests and at rates of 3, 5, 7, and 9 pounds per acre in the 1997 and 1998 tests. Since Temik is recommended for the management of thrips, no additional thrips management was required for the Temik $15 \mathrm{G}$ tests.

Chembrand 407 cotton was planted in the 1995 tests. The planting and harvesting dates for the Gadsden County and Santa Rosa County sites were May 8 and December 15, and May 15 and November 14 , respectively. DP5415RR cotton was used for the 1997 and 1998 tests. Planting and harvesting dates for the 1997 test were May 6 and December 3. Planting and harvesting dates for the 1998 test were May 15 and October 16. Soil fertility, weed control, and insect management at all sites were in accordance with standard practices (Sprenkel, 1995). Test plots were irrigated as needed at the three Gadsden County sites. Entire plots were harvested for seed cotton yield and converted to lint yield by multiplying by 0.40. Lint yield increases, costs, and returns for each application rate are based on the average of all test replicates. Individual plot data on lint yields, nematode population, and test methods are explained in more detail elsewhere (Rich and Kinloch, 2000).
The cost per pound of lint yield increase is a major criterion for evaluating economic efficiency of treatment. The cost per pound of incremental lint yield is defined as the cost of producing additional lint yield compared to the non-treated check divided by the additional yield. For Telone II and Temik $15 \mathrm{G}$ treatments, the cost per pound of incremental lint yield is equal to the nematicide price times the application rate divided by the lint yield increase. Thimet 20G was added at a rate of 5 pounds per acre to manage thrips in all the Telone II treatments, including the non-treated check. Because Thimet $20 \mathrm{G}$ was added to the non-treated check, it was not considered as an incremental cost when comparing costs within the Telone II treatments only. In addition, because Thimet $20 \mathrm{G}$ costs does not require any thrips management agent, the Thimet $20 \mathrm{G}$ cost is considered an incremental cost for Telone II when Telone II and Temik $15 \mathrm{G}$ are compared for cost effectiveness. Net return per pound increase is the sales price per pound (60 cents for purposes of this analysis) less the cost per pound increase associated with the nematicide. Partial net return is the additional return from incremental lint yield due to treatment effect. It is defined as the net return per pound increase in lint yield times the lint yield increase associated with a given application rate. All partial net returns are expressed on a per acre basis.

\section{Results and Discussion}

\section{Telone II Rates}

Kinloch and Rich (2000) found the cotton mean lint yield was significantly increased $(\mathrm{P} \leq .05)$ by the addition of Telone II in three of the four tests relative to the non-treated check. The lint yields from the 1995 Gadsden County test were not found to be significantly greater than the non-treated check although the lint yields for all treatment rates were numerically greater. No significant yield differences were found among the rates. The average lint yield increase for all application rates of Telone II was 113 pounds per acre, or $24 \%$.

Cost per pound increase in lint yield, net return per pound increase in lint yield, and partial net return were calculated for each treatment (Table 1). Partial net returns were positive for the $1.5,3$, and 4.5 
gallons per acre application rates of Telone II, with the 1.5 gallons per acre treatment rate having the greatest partial return ( $\$ 41.16$ in U.S. dollars). That increase is consistent with the results showing lint yield increases for each application rate being greater than the non-treated check but not differing significantly from each other.

\section{Temik 15G Rates}

While the test results indicated that all five Temik 15G treatment rates in the 1995 Santa Rosa County test had significantly greater lint yields than the non-treated check, this was not true for the 1995 Gasden County test where the lint yields were not significantly different from the non-treated check for any of the Temik $15 \mathrm{G}$ treatment rates (Kinloch and Rich, 2000). In the 1997 Gadsden County test, lint yields were greater in the 5 pounds per acre treatment, but not for the other four treatments where the lint yields were not significantly different from the non-treated check. Average lint yield over all the treatments increased 65 pounds per acre, or $13.3 \%$ of the non-treated check.

Partial net returns were positive for all Temik $15 \mathrm{G}$ treatments, with the exception of the 12 pounds per acre rate (Table 2). The greatest partial net return (\$33.63 in U.S. dollars) was achieved using the 5 pounds per acre application rate.

\section{Comparison of Telone II and Temik 15G Partial Net Returns}

The additional benefit of thrips management associated with Temik $15 \mathrm{G}$ must be taken into account to compare costs and returns on an equivalent basis. The cost of Thimet 20G ( $\$ 7.38$ per acre) to manage thrips is added to the cost of Telone II in Table 3. Costs and returns of Telone II treatments rates in Table 3 reflect the additional cost of Thimet $20 \mathrm{G}$ used to place the two nematicides on an equivalent benefit basis.

A comparison of partial net returns for Telone II and Temik 15G are shown in tabular form in Table 3. Temik 15G and Telone II have the same partial net return ( $\$ 34$ per acre) at preferred application rates of 1.5 gallons per acre of Telone II and 5 pounds per acre of Temik 15G. While Telone II incremental lint yields are substantially greater than Temik $15 \mathrm{G}$ lint yields (Rich and Kinloch, 2000), the greater application cost of Telone II plus Thimet 20G offsets its yield advantage. The partial net return of Telone II may be affected by the use of a different thrips management agent. Other factors such as nematicide availability, ease of application, or equipment availability may also be factors in the choice of nematicide. A decline in cotton prices would not affect the recommendations since the cost increase per pound associated with both Telone II and Temik $15 \mathrm{G}$ are nearly identical at the preferred application rates (Tables 1 and 2).

The partial net returns comparison indicates that the currently recommended rates of both Telone II ( 3 gallons per acre) and Temik $15 \mathrm{G}$ (7 pounds per acre) may be higher than desired for maximum economic return in Florida cotton (Kinloch and Rich, 2000). The data demonstrate a need to interpret results based on economic return in lieu of maximum agricultural output. Future trials should be conducted to determine whether a lower application rate than 1.5 gallons per acre of Telone II would have a greater partial net return.

\section{References}

Boehlje, M.D., and V.R. Eidman. 1984. Farm Management. New York, NY: John Wiley and Sons (pp. 237-238).

Kinloch, R.A., and J.R. Rich. 2000. Florida Cotton Nematode Management Guide. North Florida Research and Eduction Center (NFREC-Quincy) Extension Report 2000-05, Univeristy of Florida, Gainesville, FL.

Kinloch, R.A., and R.K. Sprenkel. 1994. Plant-Parasitic Nematodes Associated with Cotton in Florida. Supplement to the Journal of Nematology 26: 749-752.

Rich, J.R., and R.A. Kinloch. 2000. Influence of Temik 15G and Telone II Applications on Cotton Yield and Rotylenchulus reniformis Post-harvest Populations. Nematropica 30: 47-53.

Sprenkel, R.K. 1995. Cotton Production Guidelines. North Florida Research and Education 
Center (NFREC-Quincy) Extension Report 95-1,

University of Florida, Gainesville, FL.

United States Department of Agriculture, Florida

Agricultural Statistics Service (USDA-FASS). 2000.

http://www.nass.usda.gov/fl/rtoc0cr.htm. 
Table 1. Increases in lint yield per acre, cost per pound, net return per pound, and partial net return per acre of cotton grown in reniform nematode-infested soil treated with Telone II.

\begin{tabular}{|c|c|c|c|c|c|}
\hline $\begin{array}{c}\text { Telone II } \\
\text { Rate } \\
\text { gallons/acre }\end{array}$ & $\begin{array}{c}\text { Lint Yield } \\
\text { Increase } \\
\text { pounds/acre }{ }^{a}\end{array}$ & $\begin{array}{c}\text { Cost } \\
\text { Increase } \\
\text { dollars/acre }\end{array}$ & $\begin{array}{c}\text { Cost } \\
\text { Increase } \\
\text { dollars/pound }\end{array}$ & $\begin{array}{l}\text { Net Return } \\
\text { Increase } \\
\text { dollars/pound }\end{array}$ & $\begin{array}{c}\text { Partial } \\
\text { Net Return } \\
\text { dollars/acre }^{g}\end{array}$ \\
\hline 0.0 & 0 & $\mathrm{~N} / \mathrm{A}$ & $\mathrm{N} / \mathrm{A}$ & $\mathrm{N} / \mathrm{A}$ & $\mathrm{N} / \mathrm{A}$ \\
\hline 1.5 & 100 & 18.84 & 0.1884 & 0.4116 & 41.16 \\
\hline 3.0 & 119 & 35.34 & 0.2970 & 0.3030 & 36.06 \\
\hline 4.5 & 107 & 51.84 & 0.4845 & 0.1155 & 12.36 \\
\hline 6.0 & 124 & 68.34 & 0.5511 & 0.0489 & 06.06 \\
\hline \multicolumn{6}{|c|}{$\begin{array}{l}\text { a Lint yield increase is the average of all tests for a given treatmer } \\
b^{b} \text { Telone II cost }=\$ 11.00 \text { per gallon. } \\
{ }^{c} \text { Telone II is applied } 14 \text { to } 17 \text { days prior to planting time at an app } \\
\text { d } \text { Teleon II cost increase (dollars per acre) = Telone II cost times } \\
\text { (Thimet } 20 \text { G not considered part of Telone II cost increase becau } \\
\text { each treatment). } \\
{ }^{e} \text { Cost increase (dollars per pound) = Telone II cost increase divid } \\
{ }^{f} \text { Net return increase (dollars per pound) relative to the non-treatec } \\
\text { cents per pound cotton price). } \\
{ }^{g} \text { Partial net return = net return increase times lint yield increase. } \\
\text { N/A = not applicable. }\end{array}$} \\
\hline
\end{tabular}

Table 2. Increases in lint yield pound per acre, cost per pound, net return per pound, and partial net return dollars per acre of cotton grown in reniform nematode-infested soil treated with Temik $15 \mathrm{G}$.

\begin{tabular}{|c|c|c|c|c|c|}
\hline $\begin{array}{c}\text { Temik 15G } \\
\text { Rate } \\
\text { pounds/acre }\end{array}$ & $\begin{array}{l}\text { Lint Yield } \\
\text { Increase } \\
\text { pounds/acre }^{a}\end{array}$ & $\begin{array}{c}\text { Temik 15G } \\
\text { Cost } \\
\text { dollars/acre }\end{array}$ & $\begin{array}{c}\text { Cost } \\
\text { Increase } \\
\text { dollars/pound }\end{array}$ & $\begin{array}{c}\text { Net Return } \\
\text { Increase } \\
\text { dollars/pound }\end{array}$ & $\begin{array}{c}\text { Partial } \\
\text { Net Return } \\
\text { dollars/acre }\end{array}$ \\
\hline 00.0 & $\mathrm{~N} / \mathrm{A}$ & $\mathrm{N} / \mathrm{A}$ & $\mathrm{N} / \mathrm{A}$ & $\mathrm{N} / \mathrm{A}$ & $\mathrm{N} / \mathrm{A}$ \\
\hline 03.0 & 40 & 08.98 & 0.2245 & 0.3755 & 15.02 \\
\hline 05.0 & 81 & 14.97 & 0.1848 & 0.4152 & 33.63 \\
\hline 07.0 & 84 & 20.96 & 0.2495 & 0.3505 & 29.44 \\
\hline 09.0 & 71 & 26.75 & 0.3768 & 0.2232 & 15.85 \\
\hline 12.0 & 51 & 35.93 & 0.7045 & -0.1045 & -5.33 \\
\hline \multicolumn{6}{|c|}{ 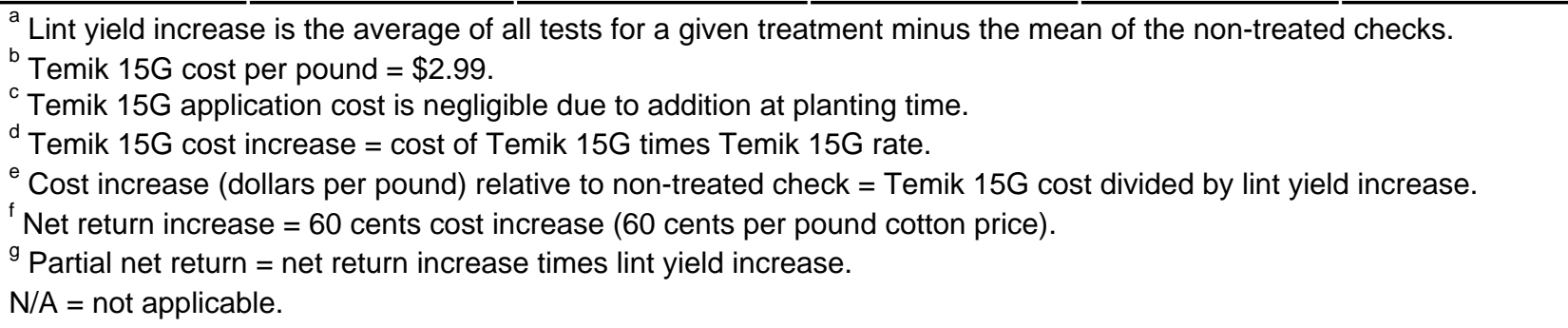 } \\
\hline
\end{tabular}


Table 3. Comparison of partial net returns of cotton grown in a Rotylenchulus reniformis-infested soil treated with Telone II or Temik 15G.

\begin{tabular}{|c|c|c|c|c|}
\hline $\begin{array}{c}\text { Telone II } \\
\text { Rate } \\
\text { gallons/acre }\end{array}$ & $\begin{array}{c}\text { Yield } \\
\text { Increase } \\
\text { pounds/acre }\end{array}$ & $\begin{array}{c}\text { Telone II } \\
\text { Cost } \\
\text { dollars/acre }\end{array}$ & $\begin{array}{c}\text { Revenue } \\
\text { Increase } \\
\text { dollars/acre }{ }^{d}\end{array}$ & $\begin{array}{c}\text { Partial } \\
\text { Net Return } \\
\text { dollars/acre }^{e}\end{array}$ \\
\hline 00.0 & $\mathrm{~N} / \mathrm{A}$ & $\mathrm{N} / \mathrm{A}$ & $\mathrm{N} / \mathrm{A}$ & $\mathrm{N} / \mathrm{A}$ \\
\hline 01.5 & 100 & 26.22 & 60.00 & 33.78 \\
\hline 03.0 & 119 & 42.72 & 71.40 & 28.68 \\
\hline 04.5 & 107 & 59.22 & 64.20 & 04.98 \\
\hline 06.0 & 124 & 75.72 & 74.40 & -1.32 \\
\hline $\begin{array}{l}\text { Temik 15G } \\
\text { Rate } \\
\text { pounds/acre }\end{array}$ & $\begin{array}{c}\text { Yield } \\
\text { Increase } \\
\text { pounds/acre }\end{array}$ & $\begin{array}{c}\text { Temik 15G } \\
\text { Cost } \\
\text { dollars/acre }\end{array}$ & $\begin{array}{c}\text { Revenue } \\
\text { Increase } \\
\text { dollars/acre }\end{array}$ & $\begin{array}{c}\text { Partial } \\
\text { Net Return } \\
\text { dollars/acre }^{e}\end{array}$ \\
\hline 00.0 & $\mathrm{~N} / \mathrm{A}$ & $\mathrm{N} / \mathrm{A}$ & $\mathrm{N} / \mathrm{A}$ & $\mathrm{N} / \mathrm{A}$ \\
\hline 03.0 & 40 & 08.98 & 24.00 & 15.02 \\
\hline 05.0 & 81 & 14.97 & 48.60 & 33.63 \\
\hline 07.0 & 84 & 20.96 & 50.40 & 29.44 \\
\hline 09.0 & 71 & 26.75 & 42.60 & 15.85 \\
\hline 12.0 & 51 & 35.93 & 30.60 & -5.33 \\
\hline \multicolumn{5}{|c|}{$\begin{array}{l}\text { a The cost of Thimet } 20 \mathrm{G} \text { ( } \$ 7.38 \text { per acre) was added to Telone II application costs from Table } 1 \text { for thrips } \\
\text { management to match the Temik } 15 \mathrm{G} \text { thrips management benefits. } \\
\text { b Telone II cost increase }=\text { cost of Telone II ( } \$ 11.00 \text { per gallon) times Telone II rate plus application rate ( } \$ 2.34 \text { per } \\
\text { acre) plus Thimet } 20 \mathrm{G}(\$ 7.38 \text { per acre). } \\
{ }^{\mathrm{c}} \text { Temik } 15 \mathrm{G} \text { cost increase }=\text { cost of Temik } 15 \mathrm{G}(\$ 2.99 \text { per pound) times Temik } 15 \mathrm{G} \text { rate. } \\
{ }^{\mathrm{d}} \text { Revenue increase }=60 \text { cents lint yield increase }(60 \text { cents per pound cotton price). } \\
{ }^{\mathrm{e}} \text { Partial net return }=\text { revenue increase minus Temik } 15 \mathrm{G} \text { cost increase. } \\
\mathrm{N} / \mathrm{A}=\text { not applicable. }\end{array}$} \\
\hline
\end{tabular}

